\title{
PENGARUH PENAMBAHAN TEPUNG KUNYIT (Curcuma domestica val)DALAM RANSUM TERHADAP KUALITAS TELUR PUYUH(Coturnix- coturnix japonica)
}

\author{
Mediatrix Amo*),J. L. P. Saerang $\left.{ }^{* *}\right)$, M. Najoan ${ }^{* * *}$ ) ; J. Keintjem $\left.{ }^{* *}\right)$, \\ Fakultas Peternakan Universitas Sam Ratulangi Manado, 95115. \\ email: media@yahoo.com
}

\begin{abstract}
ABSTRAK
Penelitian ini bertujuan untuk mengetahui kualitas telur puyuh yang menggunakan kunyit (Curcurma domestica val) dalam campuran ransum (feed additive).Ternak yang digunakan yaitu puyuh petelur (Coturnix-coturnix japonica) betina umur 5 minggu sebanyak 60 ekor dan per petakan berisi 3 ekor.Penelitian dilakukan menggunakan Rancangan Acak Lengkap (RAL) dengan 4 perlakuan dan 5 ulangan. Perlakuan yang diberikan yaitu: $\mathrm{R} 0=$ ransum kontrol, $0 \%$ tepung kunyit; $\mathrm{R} 1=$ ransum dengan 3\% tepung kunyit; R2 = ransum dengan 5\% tepung kunyit; dan R3= ransum dengan $7 \%$ tepung kunyit. Hasil penelitian menunjukkan bahwa penambahan tepung kunyit sebagai bahan perlakuan dari 3\% sampai dengan $7 \%$ memberikan pengaruh yang signifikan terhadap bobot telur dan warna kuning telur. Berdasarkan hasil dan penelitian dapat disimpulkan bahwa penambahan 7\% kunyit dalam ransum memberikan hasil yang terbaik terhadap konsumsi ransum, bobot telur, tebal kerabang telur dan warna kuning telur.
\end{abstract}

\section{Kata Kunci:Ransum, Kunyit, Telur puyuh.}

\section{PENDAHULUAN}

Puyuh merupakan salah satu jenis ternak unggas yang memiliki prospek yang cukup baik untuk dikembangkan.Coturnix-coturnix japonica banyak diternakkan untuk diambil telurnya karena produksi telurnya dapat mencapai 250-300 butir/ekor/tahun.Telur merupakan produk utama yang dihasilkan dari ternak unggas petelur seperti ayam, itik, dan puyuh.

Kunyit adalah bahasa umum untuk Indonesia, walaupun disetiap daerah ada perbedaan namanya. Dalam nomenklaturnya disebut kurkuma. Kunyit disebut juga kurkuma atau turmerik (India). Kurkuminoid merupakan zat pemberi warna kuning pada kunyit. Rimpang tanaman kunyit bermanfaat sebagai anti inflamasi, anti oksidan, anti mikroba, dan dapat meningkatkan kerja organ pencernaan unggas (Balittro, 2008).

Berdasarkan latar belakang yang sudah diuraikan diatas, maka telah dilakukan penelitian untuk melihat pengaruh penambahan kunyit (Curcuma domestica val) dalam ransum terhadap kualitas telur puyuh (Coturnix-coturnix japonica).

\section{MATERI DAN METODE PENELITIAN}

\footnotetext{
*Alumni Fakultas Peternakan

*** JurusanProduksi Ternak

**** Jurusan Nutrisi dan Makanan Ternak
}

Penelitian ini dilaksanakan

dikandang Percobaan dan 
Laboratorium Unggas Jurusan Produksi Fakultas Peternakan Universitas Sam Ratulangi. Ternak yang digunakan yaitu puyuh petelur (Coturnix-coturnix japonica betina umur 5 minggu sebanyak 60 ekor dan per petakan berisi 3 ekor. Penelitian ini menggunakan kunyit (Curcuma domestica val) sebagai bahan perlakuan. Alat yang digunakan dalam penelitian ini antara lain: 1 unit brooder untuk puyuh $D O Q$, kandang bertingkat dengan ukuran $75 \times 35 \times 15$ $\mathrm{cm}$ dan per petakan dengan ukuran $10 \times 10 \times 15 \mathrm{~cm}$ yang terbuat dari kawat, 20 buah tempat makan, 20 buah tempat air minum, 2 buah lampu pijar,1 buah penggaris, buku, pensil, timbangan digital, thermomete, camera digital,mikrometer sekrup, yolkcolour chart, kaca, piring, serta obat-obatan, dan vitamin anti stres.Ransum yang digunakan dalam penelitian ini yaitu CP11, 591 untuk puyuh umur 1-4 minggu (sebelum perlakuan) dan ransum berbentuk tepung yang dicampur sendiri untuk puyuh umur 5-11 minggu (perlakuan).

Penelitian ini menggunakan 4 macam perlakuan dan 5 ulangan dengan menggunakan 20 petak kandang, tiap petak terdiri dari 3 ekor puyuh. Perlakuan yang diberikan adalah sebagai berikut:

$$
\begin{array}{llr}
\text { R0 }= & \begin{array}{l}
\text { Ransumkontrol, 0\% } \\
\text { Kunyit } \\
=\text { Ransumdengan, }
\end{array} & \text { Tepung } \\
\text { R1 } & 3 \% \\
\text { TepungKunyit } & \\
\text { R2 } \quad \begin{array}{l}
\text { Ransumdengan, } \\
\text { TepungKunyit }
\end{array} & 5 \% \\
\text { R3 } & \begin{array}{l}
\text { Ransumdengan, } \\
\text { TepungKunyit }
\end{array} & 7 \%
\end{array}
$$

\section{Komposisi Zat-Zat Makanan}

Komposisi dan nutrisi zat-zat makanan dari setiap bahan pakan yang digunakan sebagai pakan penelitian dapat dilihat pada Tabel 1 dan Tabel 2.

\section{Variabel Penelitian}

- Bobot Telur:Telur ditimbangdenganmenggunakanti mbangan digital.

- WarnaKuningTelur:

Diukurdenganmenggunakanalatuk ur "Yolk colour chart".

- TebalKerabangTelur:Tebalkeraba ngtelurdiukurdenganmenggunaka n"Mikrometer sekrup". Mikrometersekrupmempunyaidua skala, yaituskalautamadanskalanonius (skalaputar).

Diagram alir pemeliharaan puyuh terlihat pada Gambar 1. 
Tabel 1. Komposisi Ransum Dasar

\begin{tabular}{lc}
\hline Bahan / Perlakuan & Persentase (\%) \\
\hline Jagung Kuning* & 57 \\
Bungkil Kelapa* & 4.5 \\
Dedak Halus* & 6 \\
Tepung Kacang Kedele* & 21 \\
Tepung Ikan* & 11 \\
Premix & 0.5 \\
\hline
\end{tabular}

Tabel 2. Bahan Pakan dan Kandungan Gizi

\begin{tabular}{lcccccc}
\hline \multirow{2}{*}{\multicolumn{1}{c}{ Bahan Pakan }} & PK & LK & SK & Ca & P & EM \\
\cline { 2 - 7 } & \multicolumn{1}{c}{$(\boldsymbol{\%})$} & $\mathbf{( \% )}$ & $\mathbf{( \% )}$ & $\mathbf{( \% )}$ & $\mathbf{( \% )}$ & (k.kal) \\
\hline Jagung Kuning * & 8.98 & 3.7 & 1.49 & 0.01 & 0.32 & 4.158 \\
Bungkil Kelapa* & 20.72 & 6.62 & 10.54 & 0.03 & 0.44 & 3.494 \\
Dedak Halus* & 9.35 & 8.01 & 16.13 & 0.44 & 1.13 & 4.574 \\
Tepung Kacang Kedele* & 36.35 & 11.32 & 8.99 & 0.68 & 1.46 & 4.53 \\
Tepung Ikan* & 53.97 & 10.63 & 0.55 & 5.77 & 3.29 & 4.002 \\
Kunyit* & 16.89 & 2.85 & 7.09 & 0.07 & 0 & 0 \\
\hline Sumber: *Hasil Analisis Laboratorium Jurusan Kimia Singaperbangsa Bandung (Fredy Nangoy, \\
2011). \\
*Lab. Ilmu Nutrisi dan Makanan Ternak, Universitas Padjadjaran Bandung (Najoan, 2002).
\end{tabular}

Tabel 3. Komposisi Ransum Percobaan

\begin{tabular}{lcccc}
\hline & \multicolumn{4}{c}{ Perlakuan } \\
\cline { 2 - 5 } & R0 & R1 & R2 & R3 \\
\hline Ransum Perlakuan (\%) & 100 & 97 & 95 & 93 \\
Kunyit (\%) & 0 & 3 & 5 & 7 \\
\hline Total & $\mathbf{1 0 0}$ & $\mathbf{1 0 0}$ & $\mathbf{1 0 0}$ & $\mathbf{1 0 0}$ \\
\hline
\end{tabular}

Tabel 4. Kandungan Nutrisi Bahan Pakan Tiap Perlakuan

\begin{tabular}{lcccc}
\hline \multirow{2}{*}{ Kandungan Nutrisi } & \multicolumn{5}{c}{ Perlakuan } \\
\cline { 2 - 5 } & $\mathbf{R 0}$ & $\mathbf{R 1}$ & $\mathbf{R 2}$ & $\mathbf{0 3 3}$ \\
\cline { 2 - 5 } & $\mathbf{0 . 0 0}$ & 20.18 & $\mathbf{0 . 0 5}$ & $\mathbf{0 . 0 7}$ \\
\hline Protein Kasar (\%) & 6.43 & 6.32 & 6.25 & 19.95 \\
Lemak Kasar (\%) & 4.23 & 4.32 & 4.38 & 6.18 \\
Serat Kasar (\%) & 0.81 & 0.78 & 0.77 & 4.43 \\
Kalsium (Ca) (\%) & 65.51 & 63.54 & 62.23 & 0.75 \\
Phospor (P) (\%) & 4.193 & 4.067 & 3.983 & 60.92 \\
Energi Metabolisme (kkal/kg) & & &
\end{tabular}

Keterangan: Hasil Perhitungan Berdasarkan Komposisi Zat-Zat MakanaBahan Pakan dari Tabel 2. 
Pembersihan dan sanitasi kandang

Pemeliharaan $D O Q$ dalam brooder (7 hari),

Pemberian ransumbutiran (brooder di buka) sampai umur 28 hari

Penempatan puyuh dikandang panggung secara acak

Pemberian ransum dan air minum secara terus-menerus sesuai perlakuan

R0: Ransum dasar, R1: Ransum dasar+3\% tepung kunyit,

$\mathrm{R} 2$ :Ransum dasar $+5 \%$ tepung kunyit,R3: Ransum dasar+ $7 \%$ tepung kunyit

Penimbangan sisa ransum dilakukan

tiaphari

Analisa data

Gambar1. Diagram AlirPemeliharaanPuyuhSelama Penelitian.

\section{Analisa Data}

Data yang diperoleh dianalisis dengan menggunakan analisis ragam sesuai dengan Rancangan Acak Lengkap (RAL) dan perlakuan yang memberi pengaruh nyata di uji lebih lanjut dengan menggunakan Uji
Wilayah Berganda Duncan untuk mengetahui perbedaan nilai tengah dari tiap perlakuan(Steel and Torrie, 1994). 


\section{HASIL DAN PEMBAHASAN}

\section{Konsumsi Ransum.}

Rataan konsumsi ransum puyuh per minggu selama penelitian ini dapat dilihat pada Tabel 5.Hasil penelitian menunjukan bahwa rataan konsumsi ransum yang menggunakan kunyit sebagai bahan perlakuan dan diberikan pada level yang berbeda berada pada kisaran 15.43-15.97 gram dengan rataan terendah pada perlakuan R2 dengan level tepung kunyit 5\% (15.43 g) dan rataan tertinggi pada perlakuan R3 dengan level tepung kunyit 7\% (15.97 g).

Hasil analisis keragaman menunjukan bahwa perlakuan tidak menunjukkan perbedaan yang nyata $(\mathrm{P}<0.05)$. Konsumsi ransum dengan penambahan tepung kunyit sebagai bahan perlakuan dari 3\% sampai dengan $7 \%$ tidak menunjukan perbedaan terhadap konsumsi ransum. Hal ini diduga karena kualitas ransum percobaan relatif sama atau kandungan zat-zat makanan dalam ransum percobaan mempunyai kualitas yang sama dan masih dalam kisaran kebutuhan zat-zat makanan. Hal ini sejalan dengan pendapat Wahyu (1992) yang menyatakan bahwa konsumsi ransum dipengaruhi oleh zat-zat makanan yang terkandung dalam ransum.

Tabel 5. Rataan Konsumsi Ransum(g)

\begin{tabular}{|c|c|c|c|c|c|}
\hline \multirow[t]{2}{*}{ Ulangan } & \multicolumn{4}{|c|}{ Macam Ransum } & \multirow[t]{2}{*}{ Total } \\
\hline & R0 & $\mathrm{R} 1$ & $\mathrm{R} 2$ & R3 & \\
\hline 1 & 17.77 & 16.86 & 15.29 & 17.90 & 67.81 \\
\hline 2 & 17.74 & 15.97 & 15.83 & 18.91 & 68.46 \\
\hline 3 & 14.63 & 16.93 & 14.69 & 14.13 & 60.37 \\
\hline 4 & 15.19 & 14.64 & 16.49 & 13.90 & 60.21 \\
\hline 5 & 13.10 & 14.87 & 14.89 & 15.03 & 57.89 \\
\hline TOTAL & 78.43 & 79.27 & 77.19 & 79.87 & 314.76 \\
\hline RATAAN & 15.69 & 15.85 & 15.43 & 15.97 & 62.95 \\
\hline
\end{tabular}

\section{Bobot Telur.}

Hasil pengamatan untuk bobot telur per butir dari setiap perlakuan dapat dilihat pada Tabel 6. Hasil penelitian menunjukan bahwa rataan bobot telur selama penelitian dengan menggunakan kunyit sebagai bahan perlakuan dan diberikan pada level yang berbeda berada pada kisaran 7.67-9.58 gramdengan rataan terendah pada perlakuan R0 dengan level tepung kunyit $0 \%$ (7.67 g), dan rataan tertinggi pada perlakuan R3 dengan level tepung kunyit 7\% (9.58 gram).

Analisis keragaman menunjukan perlakuan memberikan perbedaan nyata $(\mathrm{P}>0.05)$. Penambahan tepung kunyit sebagai bahan perlakuan dari $3 \%$ sampai dengan $7 \%$ menunjukan perbedaan terhadap bobot telur. Berdasarkan hasil uji wilayah berganda duncan maka perlakuan $\mathrm{R} 0=\mathrm{R} 1, \quad \mathrm{R} 2=\mathrm{R} 3 \quad$ dan $\quad \mathrm{R} 1 \neq \mathrm{R} 2$. Peningkatan bobot telur dipengaruhi oleh kandungan protein yang terkandung dalam bahan pakan dan 
sebagiannya dari kunyit. Hal ini sejalan dengan penelitian Rahmat dan Kusnadi (2008) menunjukan bahwa kunyit mempengaruhi secara nyata terhadap kandungan protein, karena dalam kunyit mengandung senyawa aktif yang tergolong antioksidan yang mampu mengatasi/mengurangi stres oksidatif (Kumar dan Sharnya, 2006), akibatnyagangguan terhadap sintesis protein dapat ditekan/diatasi sehingga kandungan protein lebih tinggi dibandingkan kontrol sehingga bobot telur meningkat. Selain itu, zat aktif curcuma yang ada pada kunyit memiliki gugus hidroksil yang mudah teroksidasi, sehinggga akan mudah pula mendonorkan gugus hidrogen dan elektron kepada radikal bebas, akibatnya muncul radikal bebas yang mengganggu sintesis protein akan dikurangi/ditekan (Priyadarsini et al., 2003.

Tabel 6. Rataan Bobot Telur (g/butir)

\begin{tabular}{cccccc}
\hline & \multicolumn{4}{c}{ Ulangan } & \multicolumn{3}{l}{ Macam Ransum } & \multicolumn{2}{l}{ Total } \\
\cline { 2 - 5 } & $\mathrm{R} 0$ & $\mathrm{R} 1$ & $\mathrm{R} 2$ & $\mathrm{R} 3$ & \\
\hline 1 & 7.94 & 8.09 & 9.77 & 10.09 & 35.89 \\
2 & 7.86 & 8.31 & 9.17 & 10.09 & 35.43 \\
3 & 7.60 & 7.83 & 9.14 & 9.77 & 34.34 \\
4 & 7.11 & 7.43 & 8.03 & 8.94 & 31.51 \\
5 & 7.83 & 8.06 & 8.46 & 9.00 & 33.34 \\
\hline TOTAL & 38.34 & 39.72 & 44.57 & 47.89 & 170.52 \\
\hline RATAAN & $7.67^{\mathrm{a}}$ & $7.94^{\mathrm{a}}$ & $8.91^{\mathrm{b}}$ & $9.58^{\mathrm{b}}$ & 34.10 \\
\hline
\end{tabular}

Keterangan: ${ }^{a b}$ Superskript dengan huruf yang berbeda pada baris yang sama menunjukan perbedaan yang nyata $(P>0.05)$.

Semakin tinggi level tepung kunyit yang dicampurkan ke dalam pakan maka semakin besar pula ukuran dan bobot dari kuning telur. Hal ini dipengaruhi oleh jumlah protein yang diperoleh melalui kunyit maupun pakan sehingga bobot telur semakin meningkat. Dengan demikian yang paling berat bobot telur yaitu pada perlakuan R3 dengan level tepung kunyit 7\% (9.58 g). Hasil penelitian bobot telur yang diperoleh selama penelitian tidak jauh berbeda apabila dibandingkan dengan Pangestuti (2009), yaitu 10-15 gram.
Tebal Kerabang Telur.

Hasil pengamatan tebal kerabang telur per butir dari setiap Perlakuan dapat dilihat pada Tabel 7.Hasil penelitian menunjukan bahwa rataan tebal kerabang telur puyuh yang diperoleh dalam penelitian yang menggunakan kunyit sebagai perlakuan dan diberikan pada level yang berbeda berada pada kisaran $0.12 \mathrm{~mm}-0.14 \mathrm{~mm}$ dengan rataan terendah pada perlakuan R0 dengan level tepung kunyit $0 \%(0.12$ $\mathrm{mm})$ dan R1 dengan level tepung kunyit $3 \% \quad(0.12 \mathrm{~mm})$ sedangkanrataan tertinggi berada pada perlakuan R3 dengan level tepung kunyit 7\% (0.14 $\mathrm{mm})$. 
Tabel 7. Rataan Tebal Kerabang Telur (mm)

\begin{tabular}{cccccc}
\hline Ulangan & \multicolumn{3}{c}{ Macam Ransum } & \multicolumn{3}{c}{ Total } \\
\cline { 2 - 5 } & $\mathrm{R} 0$ & $\mathrm{R} 1$ & $\mathrm{R} 2$ & $\mathrm{R} 3$ & \\
\hline 1 & 0.12 & 0.12 & 0.14 & 0.15 & 0.53 \\
2 & 0.12 & 0.13 & 0.14 & 0.15 & 0.55 \\
3 & 0.12 & 0.13 & 0.14 & 0.15 & 0.53 \\
4 & 0.11 & 0.12 & 0.12 & 0.13 & 0.48 \\
5 & 0.12 & 0.12 & 0.12 & 0.13 & 0.49 \\
\hline TOTAL & 0.59 & 0.62 & 0.66 & 0.71 & 2.58 \\
\hline RATAAN & $0.12^{\mathrm{a}}$ & $0.12^{\text {ab }}$ & $0.13^{\text {bc }}$ & $0.14^{\text {cd }}$ & 0.52 \\
\hline Keterangan: ${ }^{\text {abcd }}$ Superskript dengan huruf yang berbeda pada baris yang sama menunjukan perbedaan \\
yang nyata $(P>0.05)$.
\end{tabular}

$\begin{array}{ccc}\text { Hasil analisis } & \text { keragaman } \\ \text { menunjukan } & \text { bahwa } & \text { perlakuan }\end{array}$ memberikan perbedaan yang nyata $(\mathrm{P}>0.05)$. Ternyata penambahan tepung kunyit sebagai bahan perlakuan dari 3\% sampai dengan $7 \%$ menunjukan perbedaan terhadap tebal kerabang telur. Berdasarkan hasil uji wilayah berganda duncan maka perlakuan $\mathrm{R} 0=\mathrm{R} 1, \mathrm{R} 2 \neq \mathrm{R} 3$ dan $\mathrm{R} 1 \neq \mathrm{R} 2$. Bell dan Weaver (2002), persentase kerabang telur sekitar $10-12 \%$ dari berat telur.Dengan demikian pengaruh tebal kerabang telur disebabkan oleh kandungan kalsium yang terkandung di dalam bahan pakan maupun kunyit.

Dari hasil penelitian dapat dilihat bahwa tebal kerabang telur puyuh yang dihasilkan dalam penelitian tidak berbeda jauh dari penelitian lain. Tiwari dan Panda (1978) telur puyuh mempunyai ketebalan kerabang berkisar antara 0.13 sampai dengan $0.21 \mathrm{~mm}$. Menurut Rose (1997) tebal kerabang pada telur puyuh yaitu $0.13 \mathrm{~mm}$. Keadaan ini menandakan penggunaan tepung kunyitdalam ransum maupun penggunaan ransum tanpa tepung kunyit tidak menunjukkan efek negatif terhadap pembentukan tebal kerabang melainkan dapat memperbaiki kerabang telur karena kerabang merupakan kulit telur yang berfungsi melindungi isi telur dari masuknya bakteri penyebab kerusakan pada isi telur yang dapat menurunkan kualitas telur.

\section{Warna Kuning Telur.}

Hasil pengamatan untuk warna kuning telur per butir dari setiap perlakuan dapat dilihat pada Tabel 8.Hasil penelitian menunjukan bahwa rataan warna kuning telur puyuh yang diperoleh dalam penelitian yang menggunakan kunyit sebagai bahan perlakuan dan diberikan pada level yang berbedaberada pada kisaran 6.47-9.13 dengan rataan terendah pada perlakuan R0 dengan level tepung kunyit $0 \%$ (6.47), dan rataan tertinggi pada perlakuan R3 dengan level tepung kunyit 7\% (9.13). Skor warna kuning telur apabila dibandingkan dengan penelitian Rachmat (2008) tidak jauh berbeda yaitu berada pada skor ke-8. 
Tabel 8. Rataan Warna Kuning Telur

\begin{tabular}{cccccc}
\hline Ulangan & \multicolumn{4}{c}{ MACAM RANSUM } & \multirow{2}{*}{ TOTAL } \\
\cline { 2 - 5 } & $\mathrm{R} 0$ & $\mathrm{R} 1$ & $\mathrm{R} 2$ & $\mathrm{R} 3$ & \\
\hline 1 & 6.00 & 7.00 & 8.00 & 9.00 & 30.00 \\
2 & 6.00 & 7.00 & 8.00 & 8.00 & 29.00 \\
3 & 6.00 & 7.00 & 8.00 & 9.00 & 30.00 \\
4 & 7.00 & 7.00 & 8.00 & 9.00 & 31.00 \\
5 & 7.00 & 8.00 & 9.00 & 10.00 & 34.00 \\
\hline TOTAL & 32.00 & 36.00 & 41.00 & 45.00 & 154 \\
\hline RATAAN & $6.40^{\mathrm{a}}$ & $7.20^{\mathrm{b}}$ & $8.20^{\mathrm{c}}$ & $9.00^{\mathrm{c}}$ & 30.80 \\
\hline Keterangan: $^{\text {cac }}$ Superskriptdengan huruf yang berbeda pada baris yang sama menunjukan perbedaan \\
yang nyata $(P>0.05)$.
\end{tabular}

$\begin{array}{ccr}\text { Hasil analisis } & \text { keragaman } \\ \text { menunjukan } & \text { bahwa } & \text { perlakuan }\end{array}$ menunjukan perbedaan yang sangat nyata $(\mathrm{P}>0.05)$. Penambahan tepung kunyit sebagai bahan perlakuan dari 3\% sampai dengan $7 \%$ menunjukan perbedaan terhadap warna kuning telur. Berdasarkanhasil uji wilayah berganda duncan yaitu perlakuan $\mathrm{R} 0 \neq \mathrm{R} 1, \mathrm{R} 2=\mathrm{R} 3$ dan $\mathrm{R} 1 \neq \mathrm{R} 2$. Persentase kuning telur sekitar 30\%-32\% dari berat telur. Kuning telur terdiri atas membran kuning telur (vitellin) dan kuning telur sendiri. Kuning telur merupakan makanan dan sumber lemak bagi perkembangan embrio. Komposisi kuning telur adalah air 50\%, lemak 32\%-36\%, protein $16 \%$ dan glukosa $1 \%-2 \%$. Asam lemak yang banyak terdapat pada kuning telur adalah linoleat, oleat dan stearat(Bell dan Weaver, 2002). Warna kuning telur dipengaruhi oleh pakan. Apabila pakan mengandung lebih banyak karoten, yaitu xantofil, maka warna kuning telur semakin berwarna jingga kemerahan (Yamamoto et al., 1997).

Pengaruh warna kuning telur dipengaruhi oleh kandungan kimia dalam kunyit yaitu kurkumin yang dapat memberikan zat warna kuning alami terhadap kuning telur. Semakin tinggi jumlah level yang diberikan maka, semakin meningkat pula warna dari kuning telur. Warna yang paling baik untuk kuning telur yaitu pada perlakuan R3 dengan level tepung kunyit $7 \%$. Dengan demikian dapat dikatakan bahwa penggunaan kunyit sebagai bahan perlakuan dan diberikan dengan level yang berbeda-beda akan terlihat perbedaan warna kuning telur pada setiap perlakuan.

Keadaaninimenandakanpenggunaantepun gkunyitdalamransummaupunpenggunaanr ansumtanpatepungkunyittidakmenunjukka nefeknegatifterhadappembentukankuningt elurmelainkanmemberikanwarna(pigmen) kuning yang baikpadakuningtelur(yolk)sehinggamenari kperhatiankonsumenpadasaatmengkonsu msitelur.

Hasil dari uji organoleptik terbukti bahwa penambahan kunyit dapat meningkatkan penerimaan dari konsumen terhadap daging (Jarwati, 1998).Kualitastelurjugaditentukanolehinte nsitaswarnakuningtelur.Warnakuningtelur merupakankarakteristikkualitastelur yang utama. Menurut Chung (2002)warnakuningtelurberpengaruhpadas elerakonsumen.

\section{KESIMPULAN}

Berdasarkan hasil dan pembahasan pada penelitian ini dapat 
disimpulkan bahwa penambahan $7 \%$ kunyit dalam ransum memberikan hasil yang terbaik terhadap bobot telur, tebal kerabang telur dan warna kuning telur.

\section{DAFTAR PUSTAKA}

Bell, D. D. 2002. Anatomy of The Chicken. In: Bell DD and Weaver Jr WD, editor. Commercial Chicken Meat and Egg Production. Fifth edition. USA: Springer Science+Business Media, Inc.

Balittro, 2008. Budidaya Tanaman Kunyit.

http://www.balittro.go.id/incles/ kunyit. pdf. TanggalAkses : Senin, 21 Februari 2011.

Chung, T.K. 2002. Yellow and red carotenoids for eggs yolk pigmentation.10" Annual ASA Southeast Asian Feed Technology and Nutrition Workshop.Merlin Beach Resort, Phuket, Thailand.

Jarwati, F. 1998. Evaluasi Penambahan Temulawak (Curcuma xanthorriza, Rpxb.) atau Kunyit(Curcuma domestica,Val.) pada Pakan terhadap Mutu Daging Domba Lokal Ekor Tipis, Skripsi. Fakultas Teknologi Pertanian IPB, Bogor.

Kumar Vand, S.K. Sharnya. 2006. Antioxidant Studies on Some Plants. Hamdar Medicus Xlix (4): $25-36$.

Najoan, A. 2002. Disertasi nutritional evaluation of some feedstuffs from north sulawesi to finish swine. Universitas Padjadjaran

Bandung.

Nangoy, F. 2011. Hasil Analisis Laboratorium Jurusan Kimia Singaperbangsa Bandung. Bubuk Kurkuma atau Kunyit.Universitas Padjadjaran.Journal.unpad.ac.id/ ijas/article/Download/2745/2381

Priyadarsini K.I., D.K. Maity, G.H. Naik, M.S. Kumar, M.K. Unnikrishnan, J.K. Satav and H.Mohan. 2003. Role of phenolic $\mathrm{O}-\mathrm{H}$ and methylene hydrogen on the free radical reactions andantioxidant activity of curcumin. Free RadicalBiol. Med, 35 (5): 475 - 484.

Pangestuti, Yanuary. 2009. Analisis Kelayakan Usaha Peternakan Puyuh Pada Peternakan Puyuh Bintang Tiga Desa Situ Ilir, Kecamatan Cibungbulang, Kabupaten Bogor. Skripsi. Departemen Agribisnis Fakultas Ekonomi dan Manajemen Institut Pertanian Bogor. Bogor.

RoseS.P.1997. Princicples ofPoultry Science. Wallingford, UK: CAB International.

Rahmat dan Kusnadi. 2008. Pengaruh Penambahan Tepung Kunyit (Curcumadomestica Val.) dalam Ransum Yang Diberi MinyakJelantah terhadap Performan Ayam Broiler(The Effect of Curcuma domestica In Ration ThatContaining Residue Coconut Oil on BroilerPerformance)

Steel R.G.D., and J.H. Torrie. 1994. Prinsip dan Prosedur Statistika, 
Jurnal Zootek ( “Zootek”Journal), Vol.33 No.1:: 48-57 (Juli 2013) ISSN 0852-2626

Suatu Pendekatan Biometrik. Alih bahasa B. Sumanti. PT Gramedia Pustaka Utama. Jakarta.

Tiwari K.S, dan B. Panda. 1978. Production and quality characteristic of quail eggs. Indian J of Poultry Sci 13 :n 2732.
Wahyu J. 1992. Ilmu Nutrusi Ternak Unggas. Gadjah Mada University Press, Yogyakarta.

Yamamoto T., L. R. Juneja, H. Hatta, and M. Kim. 2007. Hen Eggs: Basic and Applied Science. University of Alberta, Canada. 